\title{
21st century crofting: Strengths and opportunities for community development
}

\author{
Bryan J. Hains, ${ }^{a} *$ Ronald Hustedde, ${ }^{b}$ and Kristina G. Ricketts ${ }^{c}$ \\ University of Kentucky
}

\begin{abstract}
Submitted October 5, 2012 / Revised January 13, 2013 / Accepted February 14, 2013 /
Published online May 8, 2013

Citation: Hains, B. J., Hustedde, R., \& Ricketts, K. G. (2013). 21 st century crofting: Strengths and opportunities for community development. Journal of Agriculture, Food Systems, and Community

Development, 3(3), 47-60. http://dx.doi.org/10.5304/jafscd.2013.033.002

Copyright (C) 2013 by New Leaf Associates, Inc.
\end{abstract}

\begin{abstract}
Scotland has one of the most uneven land ownership patterns in the world. In a country of 5.2 million people, about 969 people control $60 \%$ of the land. Over $20 \%$ of privately owned land in Scotland is held in some form of offshore or beneficial ownership (Committee on the Inquiry of Crofting, 2008). This land ownership pattern has a unique expression in the northern and western parts of the Scottish Highlands and Islands with a 300-year-old system of tenant farmers known as crofters. Unlike other tenant farmers across the world, crofters have gained legal rights to stay on

\footnotetext{
a * Corresponding author: Dr. Bryan J. Hains, University of Kentucky, Department of Community \& Leadership Development, 507 Garrigus Building, Lexington, Kentucky 40546 USA; +1-859-257-7578; bryan.hains@uky.edu

b Dr. Ronald Hustedde, University of Kentucky, Department of Community \& Leadership Development, 506 Garrigus Building,Lexington, Kentucky 40546 USA; +1-859-257-3186; ronald.hustedde@uky.edu

c Dr. Kristina G. Ricketts, University of Kentucky, Department of Community \& Leadership Development, 713 Garrigus Building, Lexington, Kentucky 40546 USA; +1-859257-3767; k.ricketts@uky.edu
}

the land if they are productive. While crofting has managed to survive, there are competing resources for land in rural Scotland; urbanites from England and Glasgow view rural Scotland as sites for holiday homes, thus raising land prices. Further, as with other places around the world, market forces in Scotland are merging small parcels of land into larger tracts for agriculture. This qualitative case study examines crofting on an island off the western coast of Scotland. Our primary research question is: Is there a sense of solidarity among residents about crofting for the island's economic vitality and its role in sustaining or preserving local culture?

\section{Keywords}

community development, crofting, farming systems, Scotland

\section{Introduction}

Historically, crofting emerged in Scotland as part of the Highland Clearances during the $18^{\text {th }}$ and $19^{\text {th }}$ centuries, when Highland landlords evicted people to make way for sheep ranching (Hunter, 1999; 2000). Consequently, tens of thousands of tenants were moved to North America and Australia. Others were moved to cities such as Glasgow to 
work in the growing industrial sector. However, other families were sent to poor or marginal land along the Scottish coasts. Small amounts of land (crofts) were assigned with the understanding that each family would become self-sufficient. Initially, crofting focused on livestock management, but the infertile soils made it difficult to survive on agriculture alone. Hence, crofters diversified and become astute fishermen or learned a trade to support their families. Crofting communities shared both place and customs to forge communal relationships which have secured the longevity of a rural Scottish culture (Hunter, 2000).

However, contemporary agricultural communities have met several challenges as a result of global change (Mascarenhas, 2001). Advancements in technology, increased mobility, and societal changes have caused various rural communities to question their viability as they transition to the future. This is especially true for today's Scottish crofting communities. Specific concerns include enhancing economic vitality, increasing population diversification, retaining population, enhancing local landscape and biodiversity, and maintaining cultural heritage - interconnected key elements of "sustainable communities" (Committee on the Inquiry of Crofting, 2008).

According to the Committee on the Inquiry of Crofting (2008), crofting itself could provide a platform for community viability and economic stability within rural Scotland:

Our survey provided strong evidence that crofters today see the need to assist new entrants and the succession of younger crofters as top priorities for thriving crofting communities. A strong demand for crofts should be helpful to the sustainability of crofting communities, contributing to increases in population, bringing in new ideas, energy and a commitment to manage the land well. It is also apparent that attracting population itself contributes to the prosperity of rural economies. (p. 5)

There are about 17,700 registered crofter holdings that account for $17 \%$ of the land across crofting counties. Eighty percent of the land in these counties consists of large estates owned by noncrofters. On the average, crofters receive $20 \%$ of their income from agriculture.

But what makes crofting important? How does crofting work from a community-development perspective? What does crofting mean for the larger community? These questions and several others will be addressed throughout this paper.

\section{Crofting: A Contemporary Definition}

Governances perception of crofting has evolved over the past decade. The Committee of Inquiry of Crofting final report (2008) has contributed to this evolution. More commonly known as the "Shucksmith Report," it challenged traditional perspectives toward crofting and spurred passionate discussion. Based on their analysis, the committee suggested crofters could positively impact the following areas: land and environment management and preservation; rural economic development; equitable and affordable housing; crofting governance, regulation and enforcement; and young/new entrants (Committee of Inquiry on Crofting, 2008).

The Scottish Government took heed of the suggestions of the committee. As early as October 2008 , the government began shifting responsibilities associated with the development of crofting communities to Highlands and Islands Enterprise, a public entity that fosters economic and community development in rural Scotland, based on its commitment to rural community development (Highlands \& Islands Enterprise, 2008). However, the broader influence of the Shucksmith Report was recognized in the Crofting Reform (Scotland) Act of 2010, which mandated that crofters cultivate their land. Cultivation was defined as "use of a croft for horticulture or for any purpose of husbandry, including the keeping or breeding of livestock, poultry or bees, fruit and vegetable growing, and the planting of trees and use of the land as woodlands" (Scottish Parliament, 2010, 5.C.2.a.i).

While the act seemed quite traditional, one subsection provided a broader approach to the use of the croft. This section highlighted a unique alternative: crofters were either to cultivate their land or "put it to another purposeful use" (Scottish 
Parliament, 2010, 5.C.2.a.ii). Within this legislation, "another purposeful use" was defined as a meaningful business, proposed by the crofter, which needed consent from the landlord or the Crofting Commission (Scottish Parliament, 2010, 5.C.4.a.b). This clause allowed crofters to diversify their practices and enhance their financial stability. This was critical, as most crofters subsidize household income by expanding their professional ventures due to limited land resources. Examples of diversification include fishing, manufacturing, trade business, artistry, and technological business. This vocational duality is often referred to as "occupational pluralism” (Crofters Commission, 2009).

\section{Croft Residency and Occupation}

Previous acts such as the Land Reform (Scotland) Act of 2003 stimulated population growth in rural Scotland, providing crofters with the "right to buy." Under this act, crofting communities who struggled with land negotiation could have a right to buy land from landlords for a fair market price (Scottish Government, 2003). Additionally, the Highlands and Islands Croft Entrants Scheme (2006) allowed elderly or inactive crofters to subdivide their crofts to younger crofters, reversing the population decline and age gap (The Highland Council Land and Environment Select Committee, 2006). However, it was the reform act of 2012 that secured crofters to their land. It required crofters to "reside on, or within 32 kilometres [20 miles] of, that croftee's croft" (Scottish Parliament, 2010, 33.5AA). This restricted absentee ownership and limited the use of crofts for holiday housing.

\section{Theoretical Framework}

\section{Community}

The definition of community can be complex and elusive; some have even called it a contested concept (Gallie, 1968). Contested concepts tend to be concurrently ambiguous and genuinely appealing, which emphasizes the need to specify how community is operationalized within this study. Wilkinson $(1986,1991)$ defined community as a specific type of terrestrial or social environment. Three elements provide the basis by which the presence of a community can be measured: (a) a local social ecology, (b) sufficient structures to meet the needs and common interests of the people, and (c) a field of community actions (Kaufman, 1959; Wilkinson, 1986). While each element is important to defining community, of particular interest to the researchers was the presence of community actions. Viable communities should include a domain of community actions - or "collective efforts to solve local problems and collective expressions of local identity and solidarity" (Wilkinson, 1986, p. 3). All these elements came together to form the phenomena of community as defined within this study.

\section{Community Development}

This study examined crofting within a communitydevelopment context. It can be argued that a definition of community development must satisfy two conditions: it must be distinctive, and it should be universal. Simply translated, community development must be easy to distinguish from daily community activities as well as contributing to other fields such as social welfare and applicable to diverse societies. Bhattacharyya (2004) asserted that community development is rooted in two concepts, solidarity and agency. Solidarity is the deeply shared identity and code of conduct held by the community (Bhattacharyya, 1995). Linking solidarity to community makes it possible to distinguish community from all other types of social interactions. Solidarity can be achieved in a variety of ways: (1) a shared vision or shared definition of a problem or issue, or (2) a priority for collective action.

Agency, on the other hand, is defined as the capacity to make order within one's own world. More specifically, agency is the ability to create, change, or live according to a people's own meaning systems (Giddens, 1984). It is the opposite of dependency, because community members can shape their own communities and futures.

Both agency and solidarity make up the overall theory of community development, as it is applied within this paper. In essence, solidarity occurs because people are affected significantly by those around them; living together in close physical proximity requires social structures and functions that sustain life and provide satisfaction. In com- 
munity, individuals share common interests in local institutions, schools, stores, sources of employment, and other services. The intertwining of people's lives is an important social reality, and one that plays an integral role within this study.

\section{Methods}

Our literature analysis highlighted the impact crofters historically had on rural Scottish island communities. However, in light of more recent government acts, little is known regarding the influence that contemporary crofters have on these communities. Moreover, there is a lack of literature addressing the identity and practice of the contemporary crofter. To gain deeper insight, therefore, researchers first examined the perception of the agrarian community (that is, community members who participate in agricultural production and/or land and natural resource management) of crofting identity and practice. This allowed the researchers to gain a contemporary perspective on crofting identity and practice from the community itself, thus limiting cultural and historical bias. Once the researchers were able to provide a context for the contemporary crofter within the agrarian community, they were then able to posit the broader research question, Is there a sense of solidarity among residents about crofting regarding the island's economic vitality and cultural preservation?

\section{Research Context}

During the spring of 2010, a research team from an American land-grant university traveled to the Isle of Tarbert - a pseudonym used to maintain anonymity — in Scotland for an in-depth community analysis focusing on crofting communities. The team consisted of one professor, one graduate student, and one undergraduate student. Prior to their arrival, the research team participated in a semester-long course designed to assist researchers in becoming culturally aware as well as to develop the necessary skills to complete the community analysis. This course covered topics such as historical and contemporary Scottish culture, rural community-development practices, and qualitative research methods. Upon arrival, the researchers immersed themselves in the community for a three-week term.

\section{Case Selection}

The Isle of Tarbert was selected because it had recently seen an influx in population, and it was speculated that this increase was related to new development or subdivision of established crofts (Highlands \& Islands Enterprise, 2010). Tarbert is located in the Inner Hebrides off the west coast of Scotland. It has a population of 200 inhabitants on 142 square miles of land; there are seven estate owners on the island. Most of the population lives in the southern and eastern parts of the island. There are two crofting communities on the island, Puirt and Cnuic (pseudonyms), located on two different estates. Tarbert's sparse population resembles other highlands and islands communities with crofting groups.

The northern part of the island has relatively few inhabitants. There are over 6,000 deer on the island. Other wildlife includes otters, buzzards, and hen harriers. There is a frequent ferry service between the neighboring isle and Tarbert, but direct ferry service to the mainland was discontinued in the 1970s. There is no airport on the island except for a landing strip in the northern part, which is used for emergencies. A single-lane road connects the island.

\section{Community Stakeholders}

To fully understand the crofting community and its influence on the overall Tarbert community, several stakeholders were independently interviewed. Within this context, individual perspectives were considered to be nested case studies (Patton, 2002). Nested case studies utilize individual cases to represent the overall unit of analysis, in this case the crofting community. Opinions and perceptions of each stakeholder assisted in framing the community's "overall perception of crofting influence."

Local community development officers chose stakeholders prior to the research team's arrival. Interview participants were selected based upon their diverse roles within the community as well as individual time availability. In addition, the research team interviewed several community members to provide a holistic community perspective. The demographics of interviewed stakeholders are listed in table 1. 
Journal of Agriculture, Food Systems, and Community Development

ISSN: 2152-0801 online

www.AgDevJournal.com

Table 1: Stakeholder Roles and Corresponding Definitions

\begin{tabular}{ll}
\hline Estate Owners & Individuals who own large estates, often incorporating rural communities \\
\hline Estate Managers & Individuals who manage the daily enterprises associated with the estates \\
\hline Crofters & Individuals who own or have tenure use of small land plots on larger estates \\
\hline Business Representatives & $\begin{array}{l}\text { Business owners within the Tarbert community (i. e., restaurants, hotels, and a } \\
\text { general store) }\end{array}$ \\
\hline Community Development Officers & $\begin{array}{l}\text { Individuals who work with the community to establish common priorities and who } \\
\text { assist with community sustainability }\end{array}$ \\
\hline Stalkers & Individuals who guide hunts on estates \\
\hline Crofting Commission & Individuals who monitor crofting practices on the Isle of Tarbert \\
\hline
\end{tabular}

\section{Qualitative Methodology}

Ethnographic case study was chosen as our methodology, in order to preserve the native voice and cultural uniqueness of the participants, while allowing for detailed description and analysis (Gone \& Alcántara, 2010; McMillan \& Schumacher, 2001). More specifically, the ethnographic case study method maintains cultural perspectives by:

merging one source of data (single-participant responses to open-ended interviews) with another source of data (cultural history and community artifacts) in the effort to facilitate more efficient and contextually grounded inquiry on the interrelationships between cultural and psychological processes.

(Gone \& Alcántara, 2010, p.161)

\section{Data-Collection Interviews}

Prior to the interview process, a formal interview protocol consisting of 20 questions was developed from established literature (Committee of Inquiry on Crofting Report, 2008; Scottish Government, 2003; Scottish Parliament, 2010). Then members of the research team pilot-tested the protocol with Tarbert community-development officers prior to data collection. Resulting critiques and edits were incorporated, further enhancing question clarity and delivery.

In-depth interviews were conducted with 24 people: one land owner, two estate managers, five crofters, five community business representatives, four local development officers, two crofting commission representatives, and five community members. Stakeholder responses were video recorded at an agreed-upon location; interviews lasted approximately one hour.

It is important to note that while a formal interview protocol existed, application of the protocol varied due to cultural variance. As noted by Patton, "cross-cultural inquiries add layers of complexity to the already-complex interactions of an interview" (2002, p. 391). To account for this variance, researchers implemented an ethnographic interview protocol founded on the researcher's ability to build relationships with participants (Patton, 2002). Within this framework, interviewers are consistently seen as active participants, and interviews are seen as negotiated accomplishments of both the interviewer and respondent, shaped by the context of the research and situations in which they take place (Denzin \& Lincoln, 2005). That is, rapport was established through personal discourse and individual expression by both the interviewer and the respondent. This process enhanced cultural understanding, and created a platform that allowed for deeper personal expression for all parties.

Members of the investigative team varied in age and gender. The professor and graduate student were both males in their early thirties and mid-twenties, respectively. The undergraduate investigator was a female in her early twenties. Investigator diversity was critical in order to establish rapport with a cross section of the community.

\section{Researcher Journals}

Members of the research team maintained individual journals prior to, during, and after community analysis. Journaling assisted the 
investigators as active participants in delineating initial perceptions, individual bias, cultural misconceptions, and cultural similarities and differences throughout the study. Furthermore, researcher journals were used to document informal community interactions and to define community context. Finally, journals allowed researchers to implement practices associated with reflexive ethnography, a methodology that assists researchers in explaining cultural differences through shared discourse and individual transparency (Denzin \& Lincoln, 2005).

\section{Community Artifacts}

In order to better understand Tarbert's cultural complexity, investigators collected several community artifacts. Photographs of historical agricultural people and practices were examined within the community museum, including maps, which situated the locations of historical crofts. Menus from local restaurants were collected to examine local culinary preferences and types of agricultural produce. Brochures promoting agricultural and eco-tourism were obtained, to better understand community perceptions and practices regarding the topic of inquiry. Finally, artifacts from the local press were collected to assist with explanation of research content.

\section{Data Analysis}

Data analysis began once interviews were completed and community artifacts were collected. Researcher journals were continuously referred to in order to review raw data and enhance reflective analysis. This also assisted in maintaining data credibility. The first cycle of analysis began with an in-depth review of primary data. The next step included initial or attribute coding. Attribute coding assists in examining basic descriptive information, such as research setting, participant characteristics, time frame and other descriptive variables unique to the study (Saldaña, 2009). The second form of initial coding consisted of in vivo coding. In vivo coding draws from participant culture and language to develop first cycle codes (Saldaña, 2009). In other words, in vivo coding assisted in preserving the meaning and intent of participant responses by using the participant's voice. Finally, initial in vivo codes were confirmed with each participant prior to second cycle analysis.

The second cycle of analysis consisted of focused coding, which examines the most frequent initial codes to develop master codes or assertions (Saldaña, 2009). Investigators involved with the data collection and community immersion independently coded data during each analysis cycle. Inter-rater reliability enhanced data trustworthiness. They then compared findings, establishing interrater reliability. Resulting themes were substantiated through continuous review of the initial data and cross-checked with journal documentation.

\section{Limitations}

It is worth noting that the results from this inquiry are time specific, meaning that views expressed by the community pertain only to the time when members were interviewed. Additionally, it is understood that results were derived from a small population on one rural Scottish island, and do not represent the broader population of crofters and rural communities. Furthermore, it is important to remember that this study provides an external interpretation by representatives from a southern U.S. land-grant institution over a three-week period; results cannot be generalized to other populations or times, but can inform the understanding of similar populations and practices. It is recognized that while the researchers took steps to limit cultural misconception, cultural bias still may exist (Hains, Ricketts \& Tubbs, 2012).

\section{Results}

Stakeholder roles were assigned to direct quotes to maintain their anonymity. Representative quotes were chosen to best characterize the perspectives of each group.

\section{Research Objective One}

The first objective was to examine the agrarian community's internal perception of contemporary crofting identity and practice. Stakeholders associated with agricultural production and/or land management were purposely selected, as the recent government acts maintained an agrarian link to croft establishment. The perspectives of 
stakeholders associated with this community are expressed below.

Agricultural lifestyle vs. career

Several common characteristics among agrarian stakeholders were identified throughout the study. Participant ties to both the island and community were evident. Most participants identified their roles in production agriculture as a lifestyle rather than a career. This was noteworthy, as all participants defined themself as being connected to the island and its people rather than being defined by their occupational role.

It's a lifestyle and that's the way it should be. You have to be in touch with nature in order to do this. It has to be part of your whole way of living. (Estate Manager/Stalker - 1)

It's a funny place. I mean it's been in my family for generations obviously but it gets under your skin. You get consumed by it [lifestyle]. (Estate Owner - 1)

This is more of a lifestyle than a career. We used to live in [urban city] and this is so different. There is the great outdoors; there is a whole social thing that you don't see in the cities. When you live in a small island community like this there is great respect for your elders, for each other, and for each other's space; we are part of the environment and my job is a part of that. I can't imagine doing anything else. (Crofter - 1)

\section{Neighborly behavior}

The concept of "agricultural lifestyle" was enhanced by the concept that crofters had about being "neighborly." Crofters regarded neighborly behavior as being woven into all social interactions; this included assisting others, sharing resources with one another, and serving on community committees.

The croft township will buy the machines and then everyone chips in and everyone gets to use the machines. So that each crofter doesn't have a tractor or power washer they have one for everyone, minimizing the costs; this is true with our bull as well. You just have to schedule your time.

(Crofter - 2)

$$
\begin{aligned}
& \text { *** } \\
& \text { That's just something on Tarbert, you like to belp } \\
& \text { folk out and you would like to believe you will be } \\
& \text { belped out in return. (Crofter - 1) }
\end{aligned}
$$

While these were agreed-upon tenets among crofters, the sharing of resources seemed to differ between crofters and estate owners.

There is a perception issue. We are seen as the landowners. There is a 'them' and 'us.' So when we go get our hands dirty they become sort of guarded I think. You have to earn your stripes. However, there is some sharing among estate owners, especially when counting stags. (Estate Owner - 1)

We suggest this may be due to one estate owner's decision to permanently reside on Tarbert, which historically was atypical.

Occupational pluralism and economic diversity Crofters stressed the necessity for occupational pluralism, as reliance solely on agricultural production did not produce sustainable profit. Most crofts on Tarbert encompassed small acreages located on relatively poor agricultural land; therefore, it was critical for crofters to have two or sometimes three separate occupations.

This is not the crofting of yesteryear; this is the crofting of contemporary Scotland. The new watchword is diversification...the new crofting increases options for diversification for external agricultural produce, which then increases our financial sustainability. For example I got this croft so that I could run my bus company; however, I also have a polytunnel and greenhouse for herbs and personal consumption. It will be sometime before we can produce vegetables commercially. Fortunately, the bus company allows us to build our agricultural side over time. (Crofter - 1) 


\section{*** \\ In order to sustain our income I work in the school with the K-5 children and my husband worked at the distillery and the fire brigade; we also sell herbs locally from our polytunnel and greenhouse. (Crofter - 2)}

This was true for many new crofters. Several took advantage of the Crofting Entrants Scheme (2006) and the Crofting Reform (Scotland) Act (2010) to gain residence on the island. It was evident that this new generation of crofters used the definition of "another purposeful use" quite literally. Several new community services were established, including a full-service bus system for the Tarbert School and community, graphic design companies, excavation services, and an additional public school educator. These occupations were in addition to the agricultural produce associated with their crofts.

\section{Stakebolder variance and agrarian limitations}

While there were several commonalities among agrarian participants, there were also general discrepancies regarding professional agricultural identity. The researchers first discovered the discrepancies when inquiring about crofter identity. Several stakeholders identified themselves as farmers, indicating professional differences between themselves and crofters. However, the complexities of defining "farmer" increased, as estate owners, stalkers, and land managers identified themselves as farmers yet varied in their definitions. Farmers generally owned or leased larger land parcels, allowing a larger portion of their income to be associated with selling of animal production. Most often, farmers considered themselves to be more independent and less reliant on landlords and government subsidy.

In contrast, crofters seemed to manage or own much smaller plots of land. They relied more heavily on government policy and subsidy in addition to vocational diversity to sustain their income. However, when reviewing government grants pertaining to agricultural practice, the government seemed to favor individuals associated with crofting.

\section{Market diversification}

Estate owners, farmers, and crofters expressed differences regarding economic growth and market exploration. Generally, farmers, estate managers, and stalkers envisioned their economic growth to be associated with traditional markets: stalking, venison, and cattle and sheep production. However, this was not the case with the residing estate owner, who also identified himself as a farmer. The estate owner professed exploring new and innovative ways to enhance his income, including agricultural and natural resource--based tourism, parceling land to make new crofts, and investigating niche agricultural markets.

In contrast, crofters believed market diversification could include community services, artistry, technology, and agricultural products.

\section{I think there is an opportunity for crofters on \\ Tarbert to not barter, but have some sort of \\ cooperative. Especially once everyone has their \\ polytunnels up we can diversify vegetables to a \\ broader market. (Crofter - 3)}

Another crofter spoke of hiring an advocate for marketing crofters' products.

\section{All of the crofters have their own special trade if you like, but there may be an opportunity for one person to work within a marketing position so that all the crofts on Tarbert could work together to market their products, agricultural and non- agricultural, establishing a Tarbert brand. The toughest part is our isolation and transport costs. (Crofter - 2)}

While both farmers and crofters spoke of collaborative efforts, at the time of this study there did not seem to be momentum toward initiating a collaborative group.

Government influence: A "double-edged sword"

Government regulations were deemed as a primary limitation for all participants. A dominant perspective revolved around European Union (EU) regulations associated with land management, flora and fauna conservation, and agricultural practices. Agriculturalists affirmed that the combination of 
universal regulations, reliance on government subsidy, and time allocated to securing grants limited entrepreneurial exploration:

Another barrier would probably be the usual red tape that's now forced on us and it's getting worse and worse and worse. (Estate Owner-1)

Government grants allowed estate owners and managers to enhance wildlife habitat, and in turn, conserve protected species. However, while grants subsidized initial costs, responsibilities pertaining to habitat maintenance were left to estate owners.

It is important to note that stakeholders believed government influence to be both positive and negative. This was highlighted during our interview with a local crofter:

It's kind of a double-edged sword. On one hand they [government bodies] want to keep crofting, promote crofting, and preserve crofting but they [government bodies] want to cut back on the grants and the help. Also, most of the crofting grants are based on agricultural production, not diversification. But then there is more opportunity for people today than ever before; finally people are able to utilize the land and build their house.

(Crofter - 1)

From a positive perspective, the Scottish government allowed crofters to subdivide, to purchase and establish or revitalize crofting communities.

[Government grants] provided $£ 3.000$ to start up your business plan. You also get $50 \%$ off your facilities and amenities and any fencing. It's absolutely fantastic. (Crofter - 3)

\section{Limited communication among agrarian stakeholders}

While reduced communication was not seen as a limitation, stakeholders did admit there was little or no communication between groups. The primary communication between agriculturalists on Tarbert pertained to social committees and community events, with relatively few venues to discuss the role of agriculture on the isle. In addition, the crofting communities of Puirt and Cnuic had limited communication due to their land belonging to two separate estate owners. We suggest that this gap in dialogue may be due to agriculturalists' identifying themselves as members of the Tarbert community, leaving agricultural production both farming and crofting — as an individual lifestyle.

\section{Crofting: Cooperative education}

We found that while individual expertise existed within the crofting communities, little knowledge was shared within the community. Socially, there was a neighborly spirit among crofters, yet little peer education occurred regarding agricultural practice. We identified this phenomenon early in our analysis and questioned crofters regarding this gap in cooperative education.

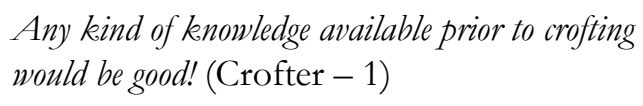

While crofters seem to be in tune with nature, it would be good to teach them how to be more environmentally friendly. They all buy fertilizer rather than using the dung on the fields.

(Crofter - 3)

There is little education regarding diversified crofting and crofting reform. It's all kind of selftaught. It would be good to have someone who could read between the lines and break it down for you. (Crofter - 1)

Crofters seemed committed to responsibilities associated with their occupational and community obligations, leaving little time for professional discussion among each other. The general response regarding the gap in shared knowledge was that it was due to the lack of time availability.

\section{Research Objective Two}

The second objective examined, "Is there a sense of solidarity among residents about crofting regarding the island's economic vitality and cultural preservation?" Our literature review outlined the historical contributions that crofters have made to 
communities within the highlands and islands. We believe this to be true of the crofting communities on Tarbert as well. Crofters expressed strong commitment to the overall Tarbert community.

\section{Contribution to island demographics}

While other Scottish island communities seem to have declined in population, Tarbert continues to thrive. In fact, the overall population of Tarbert increased by $8 \%$ due to the development of new crofts (Macniven, 2010). In light of this population growth, we asked a new crofter how he received his croft:

The Crofter's Commission throughout Scotland identified dormant crofts for various reasons. So there were loads of crofts sitting vacant for years. The Crofter's Commission saw a great opportunity to put new people into the crofts so they identified three crofts in this township. We applied to the advertisement and we were told there were about nine people who applied for the crofts. So we had to put in a business plan including our diversification plan. The township looked over the application and they and the landowner decided who they wanted to come in. Fortunately for us we got the croft. We just couldn't believe it when they said we got it. We just came up here and looked around at our croft as said, "Oh my God! This is perfect! (Crofter - 1)

We couldn't have had all of this. This was our chance to have a home of our own where we would have never had this opportunity. This finally gave us our roots back in my bome. (Crofter-3)

$$
* * *
$$

I don't think I would have moved here if I hadn't had the opportunity with the Croft Entrants Scheme because there was no affordable housing. (Crofter - 2)

Tarbert's population growth was limited by available affordable housing. For example, in May 2010, the number of holiday and rental homes (64) was greater than those that were owner occupied (51). While housing is still a primary concern, a more stable population has been established due to new croft development.

One of the primary concerns regarding population stability in fragile areas is the lack of age diversification. New Tarbert crofters have substantially enhanced the age variance, specifically those who took advantage of the Croft Entrants Scheme, which allowed seasoned crofters to divide their land for the next generation of younger crofters. This has allowed opportunities for new families to reside on Tarbert, further sustaining its population.

\section{Contribution to community infrastructure}

Community capacity can be enhanced through involvement within the social fields that make up any community (Bhattacharyya, 2004). Within this study, we identified two social fields that provide strong illustrations regarding the potential for a healthy and vibrant community: economic and community engagement.

\section{Production-distribution-consumption (Economic)}

As previously stated, occupational pluralism was seen by crofters and the resident estate owner as crucial for economic sustainability. New crofts have not only enhanced community services, they also increased available intellectual expertise. During the interview process we found that crofters had a broad range of expert knowledge. Areas of expertise included marketing, engineering, technology, artistry, craftsmanship, renewable energies, and horticultural and green practices. Tarbert crofters often have diverse skills, contributing to the overall good of the community:

\section{My busband is a jack of all trades. He does a bit of mechanics, builds houses, and makes furniture. Everyone does lots of different jobs on Tarbert. That is kind of the life here on Tarbert, you have to have different skills because there is no one to do it for you. (Crofter - 3)}

Many Tarbert crofters established "another purposeful use" for their crofts, which led to several entrepreneurial ventures, thus supporting the Tarbert community and subsidizing household income. 
Social participation (Community engagement)

Two aspects of social participation were perceived to have a noted effect upon community: relationships developed within the community, and service to the community. Many crofters took the role of community service seriously. Interviews revealed many crofters were members of one or more community committees, transitioning from occupational pluralism to community pluralism, or dual roles within a community.

I think I have been one of the longest serving members on the Community Council. I've been on it over 19 years now. I do it because I get so much from Tarbert and I want to give back. I want to do what's right for the island. (Crofter - 3)

Social participation also manifested itself through the value of relationships developed across the community. Crofters made a strong connection between crofting and their social life, making crofting more a lifestyle than merely a career choice. What's more, crofters often characterized their community according to the strong relationships built there, ultimately contributing toward the sense of community felt by crofters.

I would say that it's more of a lifestyle. Because [crofting] plays a part in our social life....I'd say $75 \%$ of our social life is crofting. (Crofter - 2) ***

First and foremost, the most important community hat [I wear] is the parent council.... That's where it all starts in the islands is with the youngsters... there is a sense of community. (Estate

Owner - 1)

\section{Community perception}

The Tarbert community provided mixed perspectives regarding the contributions of crofters and the crofting communities. The larger community found crofters to be imperative for population sustainability on Tarbert. Additionally, they found the demographic diversity refreshing and enhancing of the established culture, especially with the younger crofters. Furthermore, community members stated they benefitted substantially from the nonagricultural services provided by crofters and their diverse occupational roles. Based on informal oral feedback, there was also the perception that crofters, by the nature of their small-scale farming, complemented the natural habitat, environment, and culture of the island.

From an agricultural point of view, however, community members found little economic or community benefit in crofting. Local business owners who use or sell agricultural products voiced several concerns regarding the ability of local crofts to supply produce.

They [crofters] want to supply us with herbs.

That's great; however, no one is large enough to supply us with our demand. That's the problem; we can't get enough fruit and veg[etables]. In fact we ran out of lettuce today. (Business

Representative - 1) ***

We have given people who are crofting the opportunity to make a living by using their products from time to time. Crofting per se, there is not a lot of it that we can benefit from as of yet. Maybe in the future. (Business

Representative - 1) $* * *$

The crofters are all independent. They are very, very independent. That limits their marketability as we deal with them individually. (Business

Representative - 2)

Additionally, there were projected concerns regarding competition from potential crofter markets. Therefore, business owners had limited interaction with crofters regarding agricultural produce.

Crofting couldn't benefit me at all. People have
tried it. Usually what happens is they become in
direct competition with me. They won't sell their
produce to me because they have to sell to me at
wholesale prices. (Business Representative - 3)

Owner concerns included inability to meet seasonal demands, shortage of available growing days on 
Tarbert, limited longevity of fresh produce, limited storage, lack of processing facilities, and difficulty in establishing contracts with individual crofters.

\section{Entrepreneurial Limitations}

Some of the crofters were working as graphic artists, editors, media specialists, and web designers as a second occupation. They not only worked for external firms, but also used their skills to promote Tarbert. However, their occupational pluralism and entrepreneurial practices were hindered by the lack of high-speed Internet bandwidth. While other rural Scottish communities have such access, it was not clear why the citizens of Tarbert do not have such technology available. Finally, while occupational pluralism was admired and valued in Tarbert, it was not clear if there was a cohesive sense of direction as to how these diverse entrepreneurial activities need to complement each other to enhance the quality of life and culture, or economic prosperity.

\section{Varying Degrees of Solidarity}

While there was clearly a sense of community on Tarbert, there were varying degrees of solidarity. This was evident in the two crofting communities of Puirt and Cnuic. While they often communicated socially, they did not share ideas about production practices or sustainability with others outside their individual crofting community. Additionally, little was physically shared between the communities, such as equipment, technical expertise, labor, or external resources. While there was an upbeat sense of community life, the interviews and other data we collected suggest that there does not seem to be a collective sense of purpose or a shared vision for the future regarding crofting and other aspects of life on Tarbert, such as culture, economics, civic life, and communication patterns.

\section{Summary}

Our analysis revealed that the modern crofters have ties to, but have evolved from, their historic ancestors. On the Isle of Tarbert, the contemporary crofter generally identifies with the larger community rather than his or her occupation or agricultural practice. This may be a result of contemporary government acts assisting crofters to become active members of rural island communities by implementing the clause "another purposeful use." Crofters have changed Tarbert's demographics by providing housing for a sustainable yet diverse population. Furthermore, crofters supply several community services through their occupational and community pluralism.

While crofters seemed to identify with the larger island community, they were often solitary in nature. This may be due to their commitment to multiple occupational and societal roles. As a result, communication regarding professional practice was limited among the crofting community. Moreover, there seemed to be two components of the agrarian community, those considered to be farmers and those considered to be crofters. Lastly, while the greater Tarbert community deemed crofters as crucial for a robust community, they had mixed reviews regarding crofters' agricultural impact.

\section{Conclusions and Implications}

One of the purposes of our research was to examine whether there was a sense of solidarity among residents regarding crofting, its impact on economic vitality, and its role in sustaining or preserving local culture. Our analysis implies there was moderate impact. The following conclusions and implications intend to provide a grounded discussion of the impact that crofting can have on communities moving into the $21^{\text {st }}$ century.

Solidarity, as described earlier by Bhattacharyya (1995), is one of two key principles when detailing the effect of community development upon a community. While it appears that solidarity is beginning to surface within specific social fields in the community, it is by no means established in professional practice. Part of this may stem from how community members define themselves. When viewed as a community of place - the Isle of Tarbert and individual crofting communities crofters exhibited much more solidarity than when discussing their community as one of interest crofting practices. This becomes more complex when evaluating the variance in agrarian identities and correlating relationships such as farmer/crofter or landowner/crofter.

It is therefore recommended that crofters explore identities that are associated with commu- 
nities of interest in addition to place. Communities are not as constrained by locale as they once were; should this be any different for crofting communities? Establishing a new definition of a crofting community as a community of interest may broaden the definition and include a more cooperative approach with other local crofting communities. Moreover, there is the potential to extend these collaborative networks to other crofting-type arrangements worldwide. Overall, agrarian stakeholders described several areas where they shared commonalities both socially and professionally.

To encourage the resilience and development of crofting communities, grassroots community structures, such as agricultural cooperatives or conservation entities, could be developed to enhance political strength, marketability, and community influence. Development agencies could link from the overall Tarbert agricultural community to other agricultural communities on the island. In addition, agencies such as these could assist with both securing government grants while also limiting their need.

Discussing the possibility of cooperative grassroots agencies brings us to the question, "Do crofts have the potential to become economically self-sustaining?" While this question fundamentally appears to address finances, it also addresses culture and the need for a local paradigm shift. Local crofters are accustomed to (and possibly even enjoy) diversifying, so much so that it may lead to overcommitment. To make crofting financially viable would change the crofting lifestyle more than by just providing a suitable wage; it would also change the crofting way of life.

Building on the idea of crofting sustainability, a final aspect for consideration could be exploring local outlets for crofted products and finding new ways to brand their uniqueness. Our analysis indicates that most crofted products are only seasonally available or only available in limited quantities to make an impact on the local economy. How would this differ if crofters were able to produce on a larger, more consistent scale? By providing products to local restaurants, hotels, or nearby islands, not only could crofters create a supply-anddemand chain that would benefit crofters, but it could lead to expanding product production and creating a stronger sense of community identity and solidarity, and potentially enhancing the local economy.

Further research could include measuring the effect entrepreneurial assistance programs have on the creation of agricultural cooperatives, joint crofting partnerships, and other small businesses. This could include analysis of current social, industry, and technological infrastructures as well as analysis of potential clienteles, both local and global. Further research could also include evaluating the process of developing educational and professional venues for crofters to share business ideas and best practices.

In regard to the broader Tarbert community, most members viewed modern crofting as a community asset, specifically the increase in population, population diversity, and vocational trades and services. However, feelings about its contribution to agricultural goods and services were mixed. A venue can be provided to the community to envision how trades and services as well as agricultural goods can be linked into something more holistic rather than the current fragmented approach. We assert that community leaders should initiate a visioning process for community stakeholders by addressing such questions as: What is the shared vision for Tarbert in the next 10 to 20 years? What are the goals that can further unite the island? How can we prosper and address our social needs and issues? How can we accomplish our goals through strategic action?

The best community-visioning approaches are highly participatory and lead to action-oriented strategic plans that yield results (Walzer \& Hamm, 2012). If implemented, a community-widening vision could move Tarbert's citizens toward a greater sense of agency, one of the fundamental goals of community development, defined as the capacity of people to order their world (Bhattacharyya, 2004). The ability to act with agency allows a community to define itself and to undertake desired actions and activities that seek to improve local quality of life. Ultimately, opening up communication channels would be a first step toward developing solidarity and agency within the Tarbert crofting and larger communities. 
While we have established that the Tarbert community has received several benefits from crofting reform and the establishment of new crofts, the longevity and economic vitality of Tarbert's crofts is to be determined. The opportunities to build solidarity and agency between the two crofting communities and among the various stakeholders on the island are numerous. It is our hope that the conclusions and implications generated by our analysis will facilitate the solidarity and viability of Tarbert and of similar rural agricultural communities.

\section{Acknowledgements}

The authors would like to give special thanks to Ms. Amanda Lawrence and Mr. Bill Riley for their assistance with this study.

\section{References}

Bhattacharyya, J. (1995). Solidarity and agency: Rethinking community development. Human Organization, 54(1), 60-69.

Bhattacharyya, J. (2004). Theorizing community development. Journal of the Community Development Society, 34(2), 5-34. http://dx.doi.org/10.1080/15575330409490110

Committee on the Inquiry of Crofting. (2008). Final report. Retrieved from: http://www.croftinginquiry. org/Resource/Doc/0/0000405.pdf

Crofters Commission. (2009). Annual report 2007/2008. Retrieved from: http://www.crofterscommission.org.uk/userfiles/ documents/annual $\% 20$ report $\% 200708$.pdf

Denzin, N. K., \& Lincoln, Y. S. (2005). The sage bandbook of qualitative research ( $2^{\text {nd }} \mathrm{ed}$.). Thousand Oaks, California: Sage.

Gallie, W. B. (1968). Philosophy and the historical understanding. New York: Shocken.

Giddens, A. (1984). The constitution of society. Berkeley, California: University of California Press.

Gone, J. P., \& Alcántara, C. (2010). The ethnographically contextualized case study method: Exploring ambitious achievement in an American Indian community. Cultural Diversity and Ethnic Minority Psychology, 16(2), 159-168. http://dx.doi.org/10.1037/a0013873

Hains, B. J., Ricketts, K. G., \& Tubbs, J. (2012). Student educational responsibility: A case study of emotional response to international education.
Journal of International Agricultural and Extension Education, 19(3).

http://dx.doi.org/10:5191/jiaee.2012.19302

Highland Council Land and Environment Select Committee. (2006, August). Highlands and Islands croft entrants scheme. Retrieved from the Highland Council website: http://www.highland.gov.uk/

Highlands \& Islands Enterprise. (2008, October). Board meeting minutes. Retrieved from http://www.highland.gov.uk/

Highlands \& Islands Enterprise. (2010, March). Board meeting minutes (Land, Environment and Sustainability Strategy Group). Retrieved from http://www.highland.gov.uk/

Hunter, J. (1999). Last of the free: A history of the highlands and islands of Scotland. Edinburgh, UK: Mainstream.

Hunter, J. (2000). The making of the crofting community. Edinburgh, UK: Birlinn.

Kaufman, H. F. (1959). Toward an interactional conception of community. Social Forces, 38(1), 8-17. http://dx.doi.org/10.2307/2574010

Macniven, D. (2010). Scotland's population statistics 2009. Retrieved from http://www.scotland.gov.uk/ News/Releases/2010/08/06100549

Mascarenhas, M. (2001). Farming systems research: Flexible diversification of a small family farm in southeast Michigan. Agriculture and Human Values, 18, 391-401. http://dx.doi.org/10.1023/A:1015233512117

McMillan, J. H., \& Schumacher, S. (2001). Research in education: A conceptual introduction (5 ${ }^{\text {th }} \mathrm{Ed}$.). New York: Longman.

Patton, M. Q. (2002). Qualitative research and evaluation methods. Thousand Oaks, California: Sage.

Saldaña, J. (2009). The coding manual for qualitative researchers. Los Angeles: Sage

Scottish Parliament. (2010). Crofting Reform (Scotland) Act 2010. Retrieved from: http://www.scottish. parliament.uk/s3/bills/35-CroftReform/index.htm

Scottish Government. (2003). Land Reform (Scotland) Act 2003: Part 2. Retrieved from: http://www.scotland.gov.uk/Publications/2004/ $\underline{06 / 19478 / 38602}$

Walzer, N., \& Hamm, G. F. (2012). Community visioning. New York: Routledge.

Wilkinson, K. P. (1986). In search of the community in the changing countryside. Rural Sociology, 51(1), 1-17.

Wilkinson, K. P. (1991). The community in rural America. New York: Greenwood. 